\title{
GRAIN PRICES IN CAIRO AND EUROPE IN THE MIDDLE AGES
}

\author{
Johan Söderberg
}

\begin{abstract}
This paper compares grain prices between Cairo and Europe during medieval times. Prices were higher and more volatile in Cairo than in Europe. Over time, price levels declined in large parts of Europe but not in Cairo.

No price integration can be seen between the European Mediterranean region and Cairo. In north-western Europe, a cluster of urban centers showing similar price movements had emerged in the fourteenth century, at the latest. The Mediterranean area was not integrated into this network. Price integration in north-western Europe may have contributed to the economic advancement of this region in late medieval and early modern times.

Climatic fluctuations (in temperature as well as in the water level of the Nile) affected Cairo grain prices. In Europe, on the other hand, shortterm temperature variation did not have an appreciable impact on prices. Western European price integration cannot, it seems, be explained by the existence of a common climatic factor. Early European economic development was facilitated by a robust environment.
\end{abstract}

Research in Economic History, Volume 24, 189-216

Copyright (C) 2007 by Elsevier Ltd.

All rights of reproduction in any form reserved

ISSN: 0363-3268/doi:10.1016/S0363-3268(06)24006-0 


\section{INTRODUCTION}

This paper explores some questions related to the price history of Cairo and Europe during medieval times:

- How did price levels and trends in Cairo compare to those in Europe?

- Did price volatility in Cairo differ from European levels? Was volatility reduced over time in any of these regions?

- Can any price integration be discerned between Cairo and Europe?

- Were grain prices in Cairo affected by climatic factors to a higher degree than were European prices?

These questions can be related to a wider issue: When did the economic decline of the Near East relative to Europe begin? Did Europe perform better during the medieval era?

According to one prominent historian, Eliyahu Ashtor, the Mamluk period (1250-1517) comprises two distinct economic phases. The first century, up to the Black Death, was characterized by a stable regime, demographic growth, and economic prosperity with monetary stability. A long period of peace prevailed in Egypt. Few epidemics are recorded in Egypt as well as in Syria, suggesting an improvement of public health.

This phase of growth came to a stop with the Black Death beginning in 1347. Population declined, as well as agricultural and industrial production. The Near East suffered from impoverishment during the second half of the fifteenth century, according to Ashtor. Grain prices fell because of declining demand. Compared to the previous century, standards of living were reduced for the great majority. Egypt was still often able to export considerable quantities of wheat and barley, but could no longer store sufficient stocks of grain for times of bad harvests. Salaries for many occupations were declining. The populations of the Near East could no longer afford to eat white bread, and shifted to cheaper grains such as barley and millet. The economic deterioration of the region, Ashtor argues, contrasts with the upswing in most countries of Europe where large segments of the population enjoyed rising living standards. ${ }^{1}$

Price history thus has a central place in Ashtor's interpretation that Europe began to surpass the Near East in economic development during the late Middle Ages. His view is not without ambiguity, however. Falling nominal grain prices should have offset the decline in salaries, and it is not a priori clear which trend was dominating the course of real wages. Though Ashtor reported a large amount of price quotations for the Near East, he 
seldom converted them to Western measurement equivalents, and he rarely expressed them in silver prices that would allow convenient comparison with European prices. For reasons of time and space, the comparative study of real wages between the Near East and Europe is not carried out here.

The outline of the paper is as follows. After an introductory presentation of the data used, long-term levels, trends, and volatility in grain prices in Cairo and Europe are compared. The next section deals with aspects of price integration as indicated by correlations in short-term price fluctuations in Cairo and Europe. The third section discusses the impact of climatic factors on Cairo grain prices, e.g., through the effects of the inundation of the Nile. The paper ends with a concluding discussion.

\section{DATA}

This study relies on Cairo prices for the Mamluk period (1250-1517) already published, notably in the monumental work of Ashtor (1969). Focus is on grain prices, not only because these were decisive in determining the standard of living, but also because relatively abundant series are available, in particular, for wheat. Wheat prices are of interest since this was the most important crop in the Near East, playing a major part in the diet of the population (Mortel, 1989). Cairo market prices are usually reported by chroniclers who often give several quotations per year, referring to certain dates or to a period of one or several months. In the wheat price series used here, the average number is four quotations per year, which should reduce some of the random variability of spot prices.

Some additional Near East grain prices have been published by Ashtor (1969, pp. 392-395) for Syria and by Mortel (1989) for Mecca. The Cairo series, however, has a far better coverage and appears to behave less erratically. ${ }^{2}$ Therefore, the discussion to follow will focus on comparisons between Cairo - the largest city in the Near East - and Europe.

In order to allow comparison with European data, all prices have been converted to silver values. Grain price quotations in Cairo are originally usually given in silver or copper dirhams. These prices have been converted to silver following two steps. First, gold dinar prices were calculated utilizing the exchange ratio of the silver or copper dirham to the dinar. Second, prices in gold have been converted to silver by means of the bimetallic ratio. The gold content of the dinar is known within quite small margins of error. ${ }^{3}$ Bimetallic ratios for Cairo have been calculated by previous researchers for a large number of years. The gaps have been interpolated. As the bimetallic 
ratio was relatively stable, fluctuating around $10: 1$, this does not seem to be too risky.

Yet, conversion to silver prices is not unproblematic. A large part of the available prices refer to the fifteenth century, a century during most of which Egypt lacked a silver currency (most transactions being done in copper coins). The silver prices calculated thus should not be seen as actually having been paid in the market. Still, this procedure appears preferable to any alternative, and has the advantage of facilitating comparison with prices from Europe and other parts of the world.

\section{GRAIN PRICE LEVELS AND TRENDS}

Tables 1-3 give an overview of grain price levels and trends for Cairo and a number of European towns and cities. Table 1 covers the whole period 1260-1512, whereas Table 2 reports on the early period (before 1420) and Table 3 on the late period from 1420 onwards.

European silver prices vary between three zones. In this dataset, the first zone includes Germany and Central Europe (Stiftklosterneuberg in Austria and Strasbourg), which show low median prices of substantially less than $20 \mathrm{~g}$ of silver per hectoliter. The second zone comprises north-western Europe, where several places exhibit a median price of $20-30 \mathrm{~g}$. The third zone is characterized by a high level of more than $35 \mathrm{~g}$ of silver, documented from Valencia and Tuscany. These zones conform to those discerned by Braudel and Spooner (1967, pp. 396-397) for the fifteenth century.

To some extent, the high price level in Cairo could be an effect of the fact that famine years are disproportionately represented in the early price records from this city. As a consequence, the median, or other robust measures, are preferable to the mean as a measure of central tendency. The median wheat price in Cairo is substantially higher than at most places in Europe included in Tables 1-3. The use of the median as a robust measure of central tendency should eliminate some of the effects of observations from unusual years of scarcity. There are other alternatives as well. The 5 percent trimmed mean (the mean that would be obtained if the lower and upper 2.5 percent of values were deleted) and Huber's M-estimator are presented as well. ${ }^{4}$ The 5 percent trimmed mean usually gives higher values than Huber's M-estimator, and both these measures tend to fall between the median and the mean. The use of these additional robust measures does not change the general impression of higher wheat prices in Cairo than in Europe. 
Table 1. Grain Prices in Cairo and Wheat Prices in Selected European Cities and Towns 1260-1512, in Grams of Silver Per Hectoliter.

\begin{tabular}{lrccccr}
\hline Place & Mean & Median & $\begin{array}{c}\text { 5\% Trimmed } \\
\text { Mean }\end{array}$ & $\begin{array}{c}\text { Huber's } \\
\text { M-Estimator }\end{array}$ & $\begin{array}{c}\text { Time } \\
\text { Trend }\end{array}$ & $N$ \\
\hline Cairo, wheat & 59.2 & 44.6 & 54.5 & 47.3 & -0.136 & 131 \\
Cairo, wheat, & 48.4 & 44.4 & 47.2 & 45.1 & -0.023 & 208 \\
$\quad$ estimated & & & & & & \\
Cairo, barley & 34.6 & 25.3 & 30.9 & 27.0 & -0.041 & 75 \\
Cairo, broad & 39.1 & 32.6 & 35.3 & 31.5 & 0.049 & 74 \\
$\quad$ beans & & & & & & \\
London & 26.1 & 24.4 & 25.2 & 24.5 & $-0.615^{*}$ & 253 \\
Chester & 26.9 & 24.4 & 26.5 & 25.7 & $-0.460^{*}$ & 88 \\
Exeter & 26.5 & 24.4 & 25.7 & 24.7 & $-0.552^{*}$ & 190 \\
Douai & 29.8 & 27.9 & 28.4 & 27.9 & -0.146 & 180 \\
Leuven & 21.9 & 21.2 & 21.5 & 21.0 & $-0.232^{* *}$ & 91 \\
Brugge & 31.7 & 28.6 & 31.1 & 29.7 & $-0.716^{*}$ & 164 \\
Brussels & 23.8 & 21.4 & 23.0 & 22.2 & $-0.289^{*}$ & 110 \\
Utrecht & 32.7 & 29.7 & 31.6 & 30.2 & $-0.427^{*}$ & 148 \\
Strasbourg & 19.8 & 16.4 & 17.5 & 16.9 & $-0.191^{* *}$ & 113 \\
Stiftklosterneuberg & 13.2 & 10.2 & 11.8 & 10.6 & -0.129 & 76 \\
Tuscany & 40.5 & 36.6 & 39.3 & 37.7 & $-0.302^{*}$ & 213 \\
Valencia & 36.4 & 36.2 & 36.2 & 36.2 & $-0.287^{*}$ & 93 \\
Aragon & 26.9 & 26.7 & 26.4 & 25.9 & $-0.368^{*}$ & 66 \\
\hline
\end{tabular}

Notes and Source: Cairo prices: Ashtor (1969, pp. 283-292, 295-300); Ashtor (1977, pp. 209-211); Shoshan (1983, pp. 63-67); Allouche (1994, pp. 99-109); Popper (1957, p. 82). Cairo exchange rates dinar/dirham: Ashtor (1969, pp. 277-278); Bacharach (1983, pp. 179-180); Spufford (1986, pp. 300-306); Shoshan (1986, pp. 32-34); Allouche (1994, pp. 95-98). Strasbourg: Hanauer (1878, pp. 57, 91-101). Tuscany and Brugge: International Institute of Social History, Prices and Wages, data files by Malanima, P., and Verhulst, A. E. Utrecht: Data kindly supplied by Jan Luiten Van Zanden. Other series: Allen, Robert C.-Unger, Richard W. Database, supplemented by Verlinden $\left(1959\right.$, p. 501) for Brussels. Time trend refers to the $r_{x y}$ correlation between time and the logs of prices. One extreme wheat price quotation from Cairo, from winter 1348-1349 (Ashtor, 1969, p. 285), has not been used in this paper, since it is about 10 times higher than any other quotation in the series. The weight of $1 \mathrm{hl}$ of wheat is assumed to be $72 \mathrm{~kg}$, that of barley $62 \mathrm{~kg}$; Popper (1957, p. 100) (wheat), Hinz $(1955$, p. 57) (barley). As the hectoliter weight of beans is not known, the price is given per irdabb of $69.6 \mathrm{~kg}$. The exchange ratio between the dinar and the copper dirham for the early sixteenth century has been assumed to be 500 , which is slightly higher than the figure of $450-460$ for the late fifteenth century as reported by Spufford (1986, p. 302). Tuscany prices refer to Pisa up to 1300 , thereafter to Florence.

*Correlation significant at the 1 percent level (two-sided test).

${ }^{* *}$ Correlation significant at the 5 percent level. 
Table 2. Grain Prices in Cairo and Wheat Prices in Selected European Cities and Towns 1260-1419, in Grams of Silver Per Hectoliter.

\begin{tabular}{lccccr}
\hline Place & Mean & Median & $\begin{array}{c}\text { 5\% Trimmed } \\
\text { Mean }\end{array}$ & $\begin{array}{c}\text { Huber's } \\
\text { M-Estimator }\end{array}$ & $N$ \\
\hline $\begin{array}{l}\text { Cairo, wheat } \\
\text { Cairo, wheat, }\end{array}$ & 68.5 & 55.7 & 64.0 & 59.4 & 72 \\
$\quad$ estimated & 52.4 & 48.2 & 51.1 & 49.3 & 152 \\
Cairo, barley & 42.6 & 35.1 & 39.6 & 34.7 & 41 \\
Cairo, broad & 47.1 & 36.9 & 43.6 & 37.2 & 40 \\
$\quad$ beans & & & & & \\
London & 30.1 & 28.3 & 29.1 & 28.7 & 160 \\
Chester & 31.3 & 30.6 & 31.1 & 30.9 & 39 \\
Exeter & 30.6 & 29.0 & 29.7 & 29.2 & 102 \\
Douai & 30.6 & 29.0 & 30.1 & 29.4 & 87 \\
Brugge & 40.7 & 40.5 & 40.5 & 40.3 & 72 \\
Utrecht & 36.6 & 34.2 & 36.0 & 35.2 & 60 \\
Strasbourg & 24.3 & 18.9 & 20.6 & 19.4 & 48 \\
Tuscany & 46.0 & 41.5 & 44.7 & 42.6 & 123 \\
\hline
\end{tabular}

Notes and Source: See Table 1.

Table 3. Grain Prices in Cairo and Wheat Prices in Selected European Cities and Towns 1420-1512, in Grams of Silver Per Hectoliter.

\begin{tabular}{lccccr}
\hline Place & Mean & Median & $\begin{array}{c}\text { 5\% Trimmed } \\
\text { Mean }\end{array}$ & $\begin{array}{c}\text { Huber's } \\
\text { M-Estimator }\end{array}$ & $N$ \\
\hline Cairo, wheat & 47.8 & 32.4 & 43.7 & 36.2 & 59 \\
Cairo, wheat, & 37.7 & 37.7 & 37.5 & 37.4 & 56 \\
$\quad$ estimated & & & & & \\
Cairo, barley & 24.9 & 23.1 & 23.6 & 22.6 & 34 \\
Cairo, broad & 29.8 & 28.9 & 27.9 & 27.5 & 34 \\
$\quad$ beans & & & & & \\
London & 19.4 & 17.8 & 18.8 & 18.2 & 93 \\
Chester & 23.4 & 22.0 & 23.1 & 22.5 & 49 \\
Exeter & 21.8 & 20.7 & 21.4 & 20.8 & 88 \\
Douai & 29.1 & 25.5 & 26.8 & 26.1 & 93 \\
Leuven & 21.7 & 20.6 & 21.3 & 20.6 & 76 \\
Brugge & 24.7 & 22.6 & 24.0 & 23.5 & 92 \\
Brussels & 23.5 & 21.0 & 22.6 & 21.7 & 91 \\
Utrecht & 30.0 & 25.9 & 28.6 & 26.7 & 88 \\
Strasbourg & 16.6 & 14.9 & 15.7 & 15.1 & 65 \\
Stiftklosterneuberg & 12.2 & 10.7 & 11.6 & 10.6 & 53 \\
Tuscany & 33.0 & 30.0 & 32.2 & 31.1 & 90 \\
Valencia & 36.3 & 36.2 & 36.2 & 36.2 & 90 \\
Aragon & 26.2 & 26.6 & 26.0 & 25.7 & 55 \\
\hline
\end{tabular}

Notes and Source: See Table 1. 
Finally, all these measures of central tendency are reported for the Cairo wheat prices as estimated from the regression in Table 9 below, where information on the water level of the Nile and northern hemisphere temperature is drawn on. This estimated series is considerably longer than the observed series, since prices are estimated for all years for which water level and temperature data exist. The resulting measures of central tendency in most cases are lower in the estimated wheat prices, which seems plausible.

Cairo grain prices tend to decline over time, as seen in Tables 1 through 3 . The median wheat price in Cairo even fell below that of Valencia during the period 1420-1512. But too much weight should not be placed on comparisons between central tendency measures that do not take variance into account. It is clear that Cairo and Europe differed with regard to time trends in prices. As shown in the time trend column of Table 1, the price of wheat declined over time in most places in Europe, particularly in the north-west. Cairo does not, however, exhibit any significant decline in grain prices. This latter measurement takes variance into account and should provide a more reliable estimate of price trends.

Wheat prices in Cairo thus usually surpassed the highest prices among European cities studied, and clearly exceeded the north-western European price level. The lack of a downward trend in Cairo wheat prices differs from Ashtor's statement (1976, p. 313; 1977, pp. 212-214) that wheat prices in Egypt were falling in the long term during the Mamluk period. The observation that prices did not decline is, however, well in line with the remark of Ashtor (1976, pp. 315-316) that Arabic authors of the period complained bitterly about the decrease of cultivated area. The lords were, according to Ashtor, primarily interested in tax collection and neglected the upkeep of irrigation dams and canals, and agricultural production was also harmed by the pillaging of troops.

\section{PRICE VOLATILITY}

Table 4 reports two measures of volatility: the coefficient of variation (CV) in the arithmetic and $\log$ scales. The $\mathrm{CV}$ in the arithmetic scale gives great weight to years of high prices, since these contribute more towards a large standard deviation than do years of unusually low prices. The CV in the log scale treats years of high and low prices symmetrically.

Both volatility measures are markedly higher in Cairo than in most places in Europe. In Europe, only Strasbourg and Stiftklosterneuberg (Austria) are 
Table 4. Volatility in Grain Prices in Cairo and Europe: Coefficient of Variation (CV) in the Arithmetic and Log Scales, 1260-1512.

\begin{tabular}{|c|c|c|c|c|c|c|}
\hline \multirow[t]{2}{*}{ Place } & \multicolumn{2}{|c|}{$1260-1512$} & \multicolumn{2}{|c|}{$1260-1419$} & \multicolumn{2}{|c|}{$1420-1512$} \\
\hline & $\mathrm{CV}$ & CV (logs) & $\mathrm{CV}$ & CV (logs) & $\mathrm{CV}$ & CV (logs) \\
\hline Cairo, wheat & 0.788 & 0.200 & 0.740 & 0.193 & 0.806 & 0.198 \\
\hline Cairo, barley & 0.852 & 0.241 & 0.839 & 0.264 & 0.597 & 0.189 \\
\hline Cairo, broad beans & 0.828 & 0.229 & 0.829 & 0.247 & 0.634 & 0.193 \\
\hline London & 0.412 & 0.115 & 0.361 & 0.094 & 0.330 & 0.096 \\
\hline Chester & 0.316 & 0.095 & 0.288 & 0.087 & 0.265 & 0.082 \\
\hline Exeter & 0.370 & 0.101 & 0.355 & 0.097 & 0.253 & 0.076 \\
\hline Douai & 0.475 & 0.111 & 0.299 & 0.086 & 0.606 & 0.129 \\
\hline Leuven & 0.341 & 0.111 & & & 0.350 & 0.113 \\
\hline Brugge & 0.431 & 0.129 & 0.321 & 0.093 & 0.380 & 0.116 \\
\hline Brussels & 0.387 & 0.112 & & & 0.411 & 0.117 \\
\hline Utrecht & 0.381 & 0.101 & 0.307 & 0.084 & 0.419 & 0.104 \\
\hline Strasbourg & 0.853 & 0.176 & 0.983 & 0.200 & 0.462 & 0.142 \\
\hline Stiftklosterneuberg & 0.726 & 0.204 & 0.950 & 0.252 & 0.499 & 0.178 \\
\hline Tuscany & 0.414 & 0.108 & 0.380 & 0.093 & 0.371 & 0.105 \\
\hline Valencia & 0.161 & 0.045 & & & 0.156 & 0.044 \\
\hline Aragon & 0.255 & 0.073 & & & 0.215 & 0.064 \\
\hline
\end{tabular}

Notes and Source: See Table 1. CV is the standard deviation divided by the mean in the arithmetic scale; CV (logs) is the same calculation in the log scale. Cells based on less than 20 observations have been left blank.

similar to Cairo in terms of the $\mathrm{CV}$, in the arithmetic as well as in the log scale. As seen in Table 1, Stiftklosterneuberg has the lowest wheat prices of all European urban centers studied, so we are dealing with fluctuations around a low mean. In the log-scale CV the differentials between various places are smaller, but the general European level still is lower than in Cairo. An inspection of Fig. 1 confirms the impression that volatility was much higher in Cairo than in London.

What happened with volatility over time? The observation of declining volatility in Cairo is supported by a calculation of the $\mathrm{CV}$ in the log scale. This was reduced from 0.264 to 0.189 for barley between 1264-1419 and $1420-1512$, and from 0.247 to 0.193 for beans between the same periods. Volatility does not generally decline in the European series. There are about as many cases of increasing volatility as declining volatility, in the arithmetic as well as in the $\log$ scale. ${ }^{5}$ There is a spatial pattern, though, in the changes in volatility in Europe. Volatility tends to decline in England as well as in the Continental series of Strasbourg and Stiftklosterneuberg. On the other 


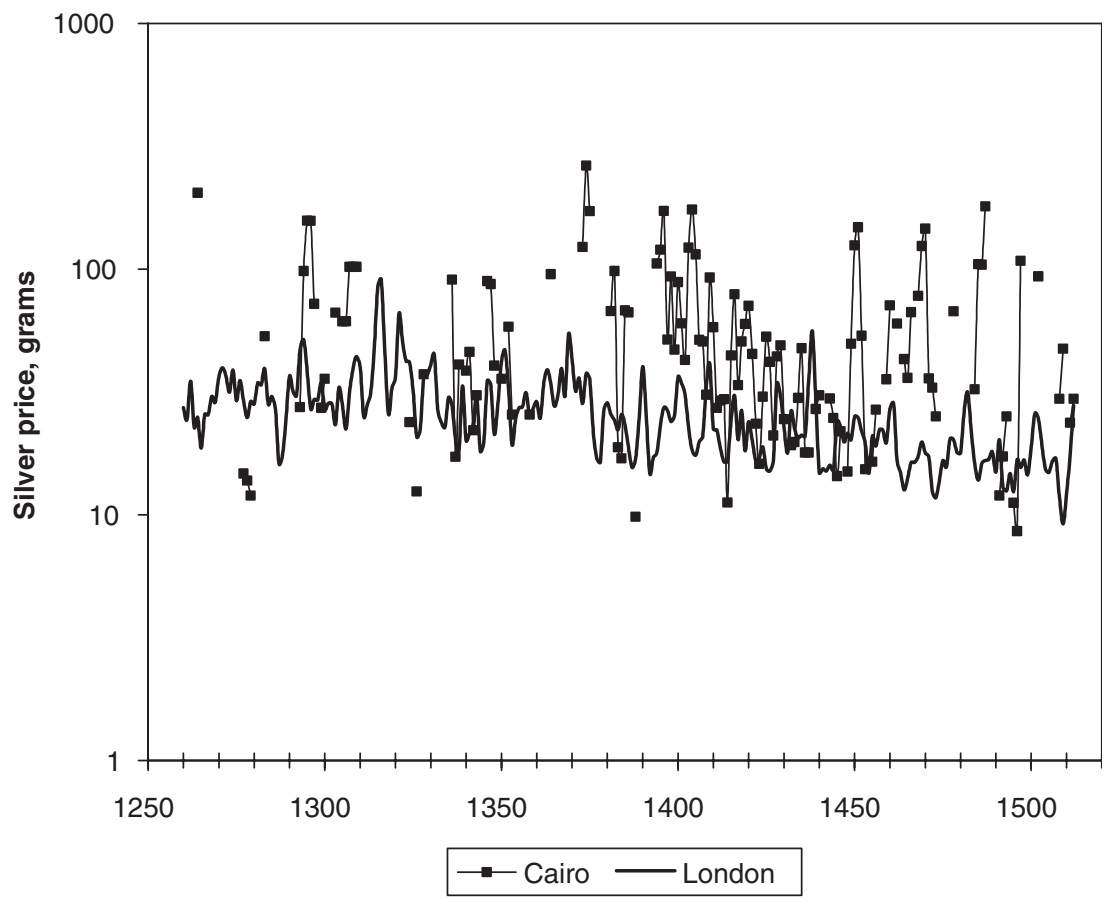

Fig. 1. Wheat Price Per Hectoliter (Log Scale) in Cairo and London, 1260-1512. Notes and Source: See Table 1.

hand, volatility tends to rise in some of the Low Countries series (Douai, Brugge, and Utrecht).

Volatility thus decreased over time in the cheap grains in Cairo. This could be the result of improved efficiency over time in the Cairo barley and beans markets, but it could also be an effect of climatic fluctuations becoming more favorable to the production of these crops. This issue will be discussed below in connection with the effects of temperature and the inundations of the Nile.

The Cairo wheat market was probably the largest in the Near East during late medieval times. Why was price volatility so high?

Cairo depended upon the flow of grains on the Nile from Upper Egypt (the southern part of the country), where the general price level was lower. In 1416, the Mamluk government purchased wheat at 530 dirhams per irdabb of $69.6 \mathrm{~kg}$ and sold it to Cairo millers for 600 dirhams. The latter 
price should have covered the cost of transport and presumably also allowed some profit. The transport cost, then, could hardly have exceeded 10 percent of the price in Cairo. Another sign of efficiency is that boats handling transports on the Nile could be quite large, carrying as much as 350 tons (5,000 irdabbs) of grain. ${ }^{6}$ Transport costs could not have been the key problem in supplying Cairo with grain.

Large amounts of grain were collected by sultans and emirs through the tax system. The Mamluk elite became the major suppliers of grain to Cairo and the other urban markets of Egypt. The sultans controlled large grain reserves, normally amounting to more than 20,000 tons. This may be compared to a cautious fifteenth-century estimate of the total consumption of grain at Cairo at 25,000 tons a year (or 1,000 irdabbs daily). Cairo's population is estimated to have been in the range of 250,000 to 500,000 by the mid-fourteenth century, declining to between 150,000 and 300,000 by the fifteenth century. The rulers' granaries would then have been sufficient to feed the population of Cairo for nearly a whole year (Shoshan, 1993, pp. 1, 58, 122, Note 46).

Sultans and emirs sometimes disrupted the normal grain trade in order to make profits, for instance by forcing merchants to buy wheat at higher prices than the market rate. For instance, al-Maqrizi reports that the state trade monopoly "kept foodstuffs out of the reach of people unless they agreed to pay the prices set by the officials" in the famine year of 1403-1404 when the Nile failed to reach its plenitude (Allouche, 1994, p. 51). Other sultans, though, took steps to supply Cairo with grain in times of bad harvests, and at times sold grain at prices that were considerably lower than the market price. It also happened that sultans distributed free grain or bread to the poor. Other measures could be taken as well. In 1336, for instance, the sultan ordered grain to be imported from Syria and Palestine. ${ }^{7}$ Egypt imported grain from Sicily, Cyprus, and other places in times of shortage. Yet, the general impression gained from Ashtor's (1983, pp. 236, 239, 465-466) major work on Levant trade is that the grain trade was not of large proportions. Trade was limited by Papal bans, and Egyptian merchants did not travel on the Mediterranean trade routes in the later Middle Ages, as they had done before the thirteenth century (Humphries, 1998).

Obviously, the measures taken by the Mamluks were not sufficient to bring wheat price volatility down to European levels. Given the limitations of foreign trade and the geography of Egypt, Cairo depended upon the grain supplies from the area surrounding the Nile, which, as will be discussed further below, varied substantially from year to year due to fluctuating water levels. Many regions in Europe, on the other hand, found themselves 
in a more mixed environment with regard to grain provisioning. This should help in explaining the higher volatility of grain prices in Cairo along with other factors such as the rapacious economic policy of the Mamluks and the restricted foreign trade.

As a consequence of the provisioning problems, famines and epidemics became more frequent in Cairo during the fifteenth century. The city was affected by 10 major famines during Mamluk rule, and food shortage was a constant fear among the inhabitants. ${ }^{8}$ Grain riots expressed popular discontent with high prices and shortages and emerged as a distinct activity in Cairo around 1350. The market inspector often was the target of public anger, but sometimes crowds also protested directly to the sultan. Occasionally, crowds responded by the pillaging of grain in parts of Cairo, or, as in 1513 , by demanding that grain shipments to Syria should cease.

In Cairo as well as in Europe, the repercussions of price volatility were dampened by the fact that the prices of bread varied less than those of grains. Some inhabitants of Cairo baked their own bread and were thus directly affected by grain price volatility. Others bought their bread from the bakers, while yet others prepared their own dough and carried it to the bakers to be baked. It is not known how many people resorted to these various ways of getting their bread. As a response to high prices in 1415, rationing was imposed on private consumers in Cairo: no person was allowed to buy more than one irdabb of grain. This suggests that the grain market for private consumption was not negligible (Shoshan, 1993, p. 63). Demand probably shifted from ready-made bread to grain in times of famine, as families then tried to hand-mill their grain to avoid paying for this work (Sabra, 2000, p. 167).

Price history always is linked to social history and the study of living conditions. There are good reasons to view price volatility as a welfare indicator. Price instability was one of the major problems of pre-industrial economies. High volatility means that consumers suffered from large fluctuations in real income and standards of living. Given the rigidity of nominal wages, the larger the fluctuations, the greater the risk that high prices would lead to poverty, famine, and health damage. Stable prices enhanced welfare (Persson, 1999, pp. 23, 31).

In this perspective, Cairo appears to have experienced more of a welfare problem than did Europe. The European situation was advantageous in two respects. First, the price level - as far back as the comparison can be made was substantially lower in London and other European cities than in Cairo. Second, European consumers should have benefited from the long-term decline in wheat prices. ${ }^{9}$ No significant downward price trend is seen in 
Cairo. The difference in price trends between Cairo and London is evident in Fig. 1.

On the other hand, the volatility in Cairo barley and beans prices (but not in wheat prices) was reduced over time. Despite this levelling of prices, volatility in barley and beans prices in Cairo for the period as a whole remained high as compared to wheat prices in Europe.

These results can be related to the argument of David Farmer, Gregory Clark, and others that an efficient market for wheat, the largest commodity of the English economy, had emerged at least by the beginning of the thirteenth century. Local prices differed little from the national price level, indicating that local weather conditions did not determine prices, and that wheat could be traded freely and extensively within the limits posed by transport costs (Farmer, 1988, pp. 742-743; Clark, 1999; Galloway, 2000). This observation accords with the fact that the volatility of English wheat markets is far smaller than in Cairo. It should be emphasized, though, that English volatility does not differ much from that of other parts of northwestern Europe. The English wheat market was not unique.

\section{PRICE INTEGRATION}

\subsection{Climate and Prices in Cairo}

Table 5 reports correlations between wheat price fluctuations in Cairo and temperature. The wheat price series has been detrended by calculating

Table 5. Correlations between Detrended Wheat Prices and Northern Hemisphere Temperature, 1260-1512.

\begin{tabular}{lcc}
\hline Place & Temperature & Temperature, lag 1 \\
\hline Cairo & $0.222^{*}$ & $0.220^{*}$ \\
London & 0.079 & 0.078 \\
Brugge & -0.051 & -0.026 \\
Douai & 0.065 & 0.085 \\
Strasbourg & 0.027 & 0.070 \\
Stiftklosterneuberg & 0.043 & -0.070 \\
Tuscany & 0.047 & 0.013 \\
Valencia & 0.093 & 0.085 \\
\hline
\end{tabular}

Notes and Source: Detrended prices are residuals from a linear time trend in logs. Prices: See Table 1. Temperature: Jones et al. (1998).

* Significant at the 5 percent level. 
residuals from a linear trend in the logs of prices. ${ }^{10}$ The temperature series used is a northern hemisphere temperature reconstruction by Jones, Briffa, Barnett, and Tett (1998). This series combines evidence from tree rings, ice cores, and historical documents, and is often quoted by climatologists, e.g., Berger (2002, p. 4). ${ }^{11}$ Temperature variation seems to have had an impact on Cairo prices, unlike the situation in Europe. Climatic factors related to Cairo prices will be discussed further below in connection with the inundations of the Nile.

The short-term movements of wheat prices in Cairo do not appear to be linked to European prices. In particular, Mediterranean wheat prices (Tuscany and Valencia) are uncorrelated with Cairo prices. ${ }^{12}$

\subsection{The North-Western European Cluster of Integration}

Several urban centers in Europe appear to have been economically integrated to a considerable degree. Table 6 summarizes the correlations between the residuals from a time trend of the $\log$ of wheat prices. The covariation is far from being restricted to England. London and Exeter prices correlate not only with each other but also with prices in Brugge, Leuven, and the French inland town of Douai; in addition, there is a weaker correlation with Brussels. London also correlates with Strasbourg. Utrecht, Brugge, Leuven, Douai, and Strasbourg are centrally placed in this network: prices there are significantly correlated (at the 1 percent level) with all other towns included in Table 6.

There thus existed a cluster of cities and towns in north-western Europe within which short-term price movements were similar. Coastal as well as

Table 6. Correlations between Detrended Wheat Prices (Residuals from a Linear Time Trend, Logs) in European Cities and Towns, 1260-1512.

\begin{tabular}{llllllll}
\hline Place & Exeter & Utrecht & Brugge & Leuven & Brussels & Douai & Strasbourg \\
\hline London & $0.797^{*}$ & $0.363^{*}$ & $0.364^{*}$ & $0.413^{*}$ & $0.284^{*}$ & $0.383^{*}$ & $0.541^{*}$ \\
Exeter & & $0.288^{*}$ & $0.291^{*}$ & $0.445^{*}$ & 0.186 & $0.198^{*}$ & $0.327^{*}$ \\
Utrecht & & & $0.735^{*}$ & $0.641^{*}$ & $0.546^{*}$ & $0.532^{*}$ & $0.422^{*}$ \\
Brugge & & & & $0.664^{*}$ & $0.666^{*}$ & $0.570^{*}$ & $0.440^{*}$ \\
Leuven & & & & & $0.683^{*}$ & $0.588^{*}$ & $0.622^{*}$ \\
Brussels & & & & & & $0.371^{*}$ & $0.570^{*}$ \\
Douai & & & & & & & $0.484^{*}$ \\
\hline
\end{tabular}

Notes and Source: See Table 1.

* Significant at the 1 percent level. 
inland towns were part of this network. Among inland towns, Leuven and Brussels show strong internal connections, as do Leuven and Douai. It appears as if contacts were systematic in several directions between England, the Netherlands, and France. ${ }^{13}$ Strasbourg also belongs to this cluster, since prices there vary with those at several other towns: London, Utrecht, Douai, Brugge, Brussels, Leuven, and Douai.

Price integration was weaker outside north-western Europe. Tuscany, for instance, shows significant correlations only with Valencia and Douai, and not very strong ones $\left(r_{x y}=0.300\right.$ and 0.182 , respectively). Valencia correlates, apart from Tuscany, only (and rather weakly) with London and Aragon. Aragon shows no other significant correlation than with Valencia. The Mediterranean region thus stands largely separate from the northwestern cluster; it is also internally less integrated than is north-western Europe. ${ }^{14}$ The north-western cluster was separated from the Mediterranean market. In central Europe, Stiftklosterneuberg (Austria) has an even more peripheral position, price fluctuations there being unrelated to those anywhere else in this dataset.

Stephan Epstein (2001) has advanced the general argument that political centralization gave rise to greater market integration during the late medieval era. According to him, jurisdictional fragmentation was the main cause of grain price volatility. Epstein specifically studies the expansion of Florence, which allowed weak rural communities to establish markets and fairs despite urban resistance. The strengthening of government facilitated road improvements, lowered transport costs, and reduced tariffs on domestic trade (Epstein, 2000, pp. 99-108, 116-121). While this stimulated market integration within north Italy, it is apparently not the type of price integration across rather large distances and several political borders that we can see in north-western Europe.

The observed correlations between various European towns could in principle be the result of a common climatic factor affecting yields and prices. This appears not to be the case, however, with regard to short-term movements. As reported in Table 5, correlations between northern hemisphere temperature and the residuals from a linear time trend of the log of wheat prices are practically zero. The hypothesis of a common temperature effect on European wheat prices should not be totally discarded, but it is unlikely to have been substantial, and certainly not sufficiently strong as to generate the much higher correlations in Table 6.

A striking result from James Masschaele's study of transport costs in medieval England is that these costs were remarkably low in the fourteenth century. The ratio of the cost of land transport to river transport to sea 
transport was about $8: 4: 1$. While sea and river transport were clearly cheaper than land transport, the latter cost was not prohibitive. A land trip of 10 miles raised the price of wheat by only 4 percent. Moreover, Masschaele finds no evidence of land transport costs being reduced from the fourteenth to the eighteenth century. ${ }^{15}$ From the point of view of transport economics, nothing should have prevented a medieval price integration of the type observed above in north-western Europe. A calculation from a real example reported by Masschaele gives the result that the cost of transporting $42 \mathrm{hl}$ of wheat by sea from Hull to Ostende, a distance of 225 miles, added 24 percent to the price at Hull. ${ }^{16}$ This cost should have been far from prohibitive, and most grain transports certainly were carried out at shorter distances.

Why, then, did the north-west distinguish itself from other parts of Europe with respect to price integration? Peter Spufford provides part of the answer. As a consequence of the urban growth of the thirteenth century, the cities of the Netherlands could not be provisioned by means of nearby food supplies only. Substantial amounts of grain were sent to Flanders from northern France. And this was not enough. Grain was also brought from the regions around the Rhine and the Meuse, from southern England, and from the Baltic. Internal waterways provided efficient means of transport for the grain coming in from Antwerp and Amsterdam. The total urban population of Flanders, Brabant, and Holland approached half a million by the mid-fifteenth century (Spufford, 2002). The feeding of this population required a large and regular grain trade across political borders.

The Baltic trade, taking place on a regular scale at least from about 1300 onwards and growing strongly in the fifteenth century, was of importance not only in allowing a higher degree of urbanization but it also exerted downward pressure on grain prices in England and other parts of northwestern Europe. ${ }^{17}$ As shown in Table 1, wheat prices declined in the long term in many urban centers in the north-west. This clearly marks a difference between the price history of north-western Europe and that of Egypt.

Land transport in Europe seems to have revived in contrast to sea transport in the second half of the fifteenth century. One reason for this could be the improved safety of land transport. France and several other parts of Europe were increasingly pacified with the creation of standing armies. Sea transport in the Mediterranean, on the other hand, became less safe. The bitter wars between Muslims and Christians brought higher risk. Piracy was a serious additional problem in the western Mediterranean (Spufford, 2002). Sea transport costs in the Mediterranean may thus have risen, not only relative to the cost of land transport but also in relation to the cost of sea 
transport in north-western Europe. This should have given the north-western cluster a cost advantage compared to shipping in the Mediterranean.

It is possible, though not demonstrated, that north-western Europe was characterized by unusually low land and sea transport costs. In fourteenthcentury western England, Exeter apparently had a choice of trading grain with London and eastern England on one hand, or Brittany on the other. Campbell (1997) argues that the grain trade in England had declined by 1400 as a result of demographic recession and decreasing market participation on the side of the seignorial economy. A well-integrated coastal wheat market embracing southern England, Flanders, Picardy, Normandy, and other parts of the near continent existed before the Black Death, but declined after the plague.

Is there any sign that price integration was weak in the period following the Black Death? In order to explore this issue, the available series have been divided into two periods, 1360-1419 and 1420-1512. Tables 7 and 8 report the correlations between detrended wheat prices (residuals from a linear time trend of the logs of prices). Owing to sparse data, this subdivision into periods cannot be done for all towns included in Table 6.

Correlations between three pairs of urban centers - London-Exeter, London-Brugge, and London-Douai - are similar across the two periods, indicating a considerable stability. The most notable change is that Strasbourg is being integrated into the north-western cluster after 1420, as prices in this town begin to vary with those in Brugge, Douai, and London. Also, the connection between Brugge and Douai is somewhat strengthened. The Exeter-Brugge and Exeter-Douai links are however weakened after 1420. The overall impression is one of expansion of the network eastwards to Strasbourg, while the position of Exeter became more peripheral.

Table 7. Correlations between the Residuals from a Linear Time Trend of the Log of Wheat Prices in European Cities and Towns, 1360-1419.

\begin{tabular}{lcccc}
\hline Place & Exeter & Brugge & Douai & Strasbourg \\
\hline London & $0.819^{*}$ & $0.428^{*}$ & $0.373^{*}$ & 0.341 \\
Exeter & & $0.419^{*}$ & $0.278^{* *}$ & 0.141 \\
Brugge & & $0.474^{*}$ & 0.284 \\
Douai & & & & 0.351 \\
\hline
\end{tabular}

* Significant at the 1 percent level.

** Significant at the 5 percent level. 
Table 8. Correlations between the Residuals from a Linear Time Trend of the Log of Wheat Prices in European Cities and Towns, 1420-1512.

\begin{tabular}{lllll}
\hline Place & Exeter & Brugge & Douai & Strasbourg \\
\hline London & $0.737^{*}$ & $0.374^{*}$ & $0.461^{*}$ & $0.497^{*}$ \\
Exeter & & $0.233^{* *}$ & 0.207 & $0.267^{* *}$ \\
Brugge & & $0.709^{*}$ & $0.600^{*}$ \\
Douai & & & & $0.566^{*}$ \\
\hline
\end{tabular}

Notes and Source: See Table 1.

* Significant at the 1 percent level.

** Significant at the 5 percent level.

The north-western cluster clearly came into existence well before 1420 . Several of the links within it were maintained between the post-plague decades and the later medieval era. Price integration in the north-western region is evident before as well as after the mid-fourteenth century. While Galloway and Campbell find indications of English grain markets contracting after the Black Death, results in this paper point rather to the possibility that the disruptions were counterbalanced by the continued existence and even growth of the north-western grain trade network. This is more in line with Epstein's (2001) argument that markets expanded as a result of rising labor productivity and increased political centralization, reducing the costs of trade in the century after the Black Death.

In explaining the successful formation of the north-western cluster we should then study the changing role of political and other barriers to the expansion of trade. Galloway points at several factors as significant in the early formation of an efficient internal grain market in England, including relative security for traders and travelers, the regular access of peasants to market places, a relatively stable currency, standardization of weights and measures, the absence of large tariffs, and the means of enforcing contracts and settling disputes. These transaction costs are all linked to the emergence of a centralized political structure, which seems to have been more firmly established in England than in many parts of Europe (Galloway, 2000).

Still, what remains to be explained is the existence of an integrated urban network crossing the political borders of north-western Europe, in which England did not necessarily hold the most central position. The spatial perspective should be widened, and the role of transaction costs for the growth of the north-western cluster of integration deserves to be studied more closely. 


\section{CLIMATE, INUNDATION OF THE NILE, AND CAIRO GRAIN PRICES}

The yearly inundation of the Nile is reported by contemporary observers to have been of great importance not only for actual harvests, but also for the formation of short-run price expectations. Near Cairo, the river reached its lowest point in mid-May and its maximum in late September. The minimum as well as the maximum were measured by means of the Nilometer. The critical level was 16 cubits (around 9.3 meters): if the Nile reached that height, people felt confident that the harvest would be good. This level was normally reached in July or August and was publicly proclaimed. Announcement of the rising of the Nile was prohibited until it had reached 16 cubits. In 1462, the sultan even contemplated destroying the Nilometer as a means of counteracting speculation and unrest (Shoshan, 1993, p. 62; Rabie, 1981, p. 60).

Grain dealers could take advantage of the anxiety among the population when there were signs that the annual flood might be insufficient. Merchants were accused of holding back supplies at these occasions, waiting for prices to rise. Harvest predictions based on the minimum level of the Nile also influenced the price of grain by stimulating actors to release surplus from previous years (Popper, 1951, p. 215).

Yet, researchers do not agree upon the impact of inundation on grain prices. Boaz Shoshan argues that inundation in the period 1450-1470 cannot explain variations in wheat prices since water levels nearly always exceeded the critical level of 16 cubits. More generally, Shoshan (1983, pp. 57-59) emphasizes the role of monetary factors behind wheat price trends, and strongly plays down all real factors.

Surprisingly, no systematic test has to my knowledge been made of the effects of inundation upon grain prices. Sufficient data to do it are available. Table 9 reports the results of a regression analysis of wheat prices (residuals from a linear time trend in logs) upon the water level. Since low minimum and maximum water levels should have lowered yields (or harvest expectations) and pushed up prices, the expected sign of both coefficients is negative. A temperature estimate for the northern hemisphere is also included as an explanatory variable. As higher temperatures should increase the risk of drought and higher prices, the sign of this coefficient should be positive.

The results in panel (A) of Table 9 indicate that the water level of the Nile indeed affected grain prices in the short term, just as stated by contemporary observers. The effect of the variation in the minimum level is highly statistically significant with regard to all three types of grain. The maximum 
Table 9. Results of Regression Analysis of Cairo Grain Prices upon the Water Level of the Nile and Temperature, 1264-1512.

\begin{tabular}{lrrr}
\hline Parameter & \multicolumn{1}{c}{$b$} & $t$-value & Prob. $(t)$ \\
\hline Panel A: Dependent variable: Wheat & & & \\
Constant & 0.187 & 1.618 & 0.109 \\
Minimum level (meters) & -0.322 & -4.048 & 0.000 \\
Maximum level (meters) & -0.291 & -2.171 & 0.032 \\
Temperature (degrees C) & 0.896 & 2.535 & 0.013 \\
$R^{2}=0.235$; adjusted $R^{2}=0.212$; DW =1.63; N=108 & & & \\
Panel B: Dependent variable: Barley & & & \\
Constant & 0.258 & 1.598 & 0.115 \\
Minimum level (meters) & -0.370 & -4.220 & 0.000 \\
Maximum level (meters) & -0.268 & -1.605 & 0.113 \\
Temperature (degrees C) & 1.179 & 2.294 & 0.025 \\
$R^{2}=0.309 ;$ adjusted $R^{2}=0.277$; DW $=1.75 ; N=69$ & & & \\
Panel C: Dependent variable: Beans & & & \\
Constant & 0.218 & 1.441 & 0.154 \\
Minimum level (meters) & -0.359 & -4.163 & 0.000 \\
Maximum level (meters) & -0.329 & -2.033 & 0.046 \\
Temperature, (degrees C) & 0.981 & 2.022 & 0.047 \\
$R^{2}=0.303$; adjusted $R^{2}=0.271 ;$ DW $=1.83 ; N=69$ & & & \\
\hline
\end{tabular}

Notes and Source: Prices: See Table 1. Nile minimum and maximum levels: Popper (1951, pp. 212-214), Toussoun (1922, pp. 143-145). The chronology of the Toussoun series differs from the Popper series and has been adjusted to the latter. Tessmperature: Jones et al. (1998). Grain prices are residuals from a linear time trend, in logs. Minimum and maximum levels of the Nile are residuals from a linear time trend, in the arithmetic scale. The temperature series is given as deviations in degrees $\mathrm{C}$ in the northern hemisphere versus the 1961-1970 mean. All variables are measured at lag zero.

level appears to be of somewhat less importance and is significant at the 5 percent level in the case of wheat and beans but not with respect to barley. Temperature variation had an additional effect in the expected direction on prices of all three types of grain. Real factors did influence prices. ${ }^{18}$

The wheat market should be expected to have been more spatially integrated than the market for lower-priced grains such as barley and beans. Trade should have been taking place over wider distances in the wheat market, since its price could bear higher transport costs. Trade thus would reduce the supply variations for wheat to a larger extent than was the case for low-price grains. Climate effects should then be larger on the prices of barley and beans than on wheat prices. Is this assumption supported by the data? 
Panels (B) and (C) of Table 9 report the results from an identical set of explanatory variables as in Panel (A) but with barley and beans, respectively, as dependent variables. The key result is that the combined explanatory value of the model is better for the cheap grains than for wheat. Climatic variation had stronger repercussions on prices in the barley and beans market than on wheat. This result is in accordance with expectations and supports the hypothesis that the higher relative cost in transporting the cheaper grains limited the extent of their markets. Variation in the Nile minimum level and temperature had a stronger impact on the price of the cheaper grains than on wheat.

The above discussion dealt with short-term price changes only. In the longer term as well, changes in the inundation seem to have affected prices. At least this is the impression from Fig. 2, showing the minimum level of the Nile and the price of wheat. The declining price trend from the first decade of the fifteenth century up to the late 1430s corresponds fairly well to the rising trend in the water level of the Nile.

To some extent, climatic factors determining the water level of the Nile appear to have had the long-run effect of reducing prices, presumably by

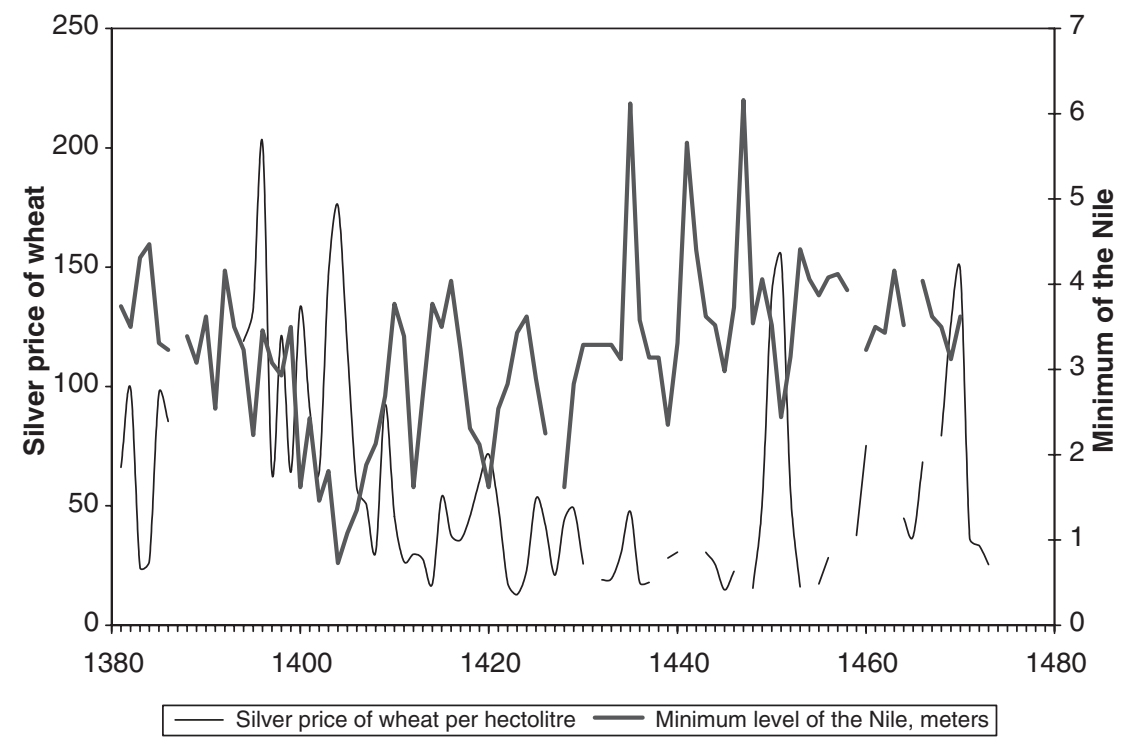

Fig. 2. The Minimum Level of the Nile and the Price of Wheat in Cairo, 1381-1473. Notes and Source: Prices: See Table 1. Nile minimum levels: Popper (1951, pp. 212-214). 
influencing yields. With time, the plenitude (level of 16 cubits) of the Nile came earlier, and the river reached higher water levels (see also Herring, 1979, pp. 55-56). Late plenitudes could be harmful. The worst possible situation was the one in which the river did not reach plenitude at all. There were only 5 years between 1251 and 1522 in which plenitude was not reached. Before the mid-eleventh century, failure of plenitude was much more common (e.g., in 65 years in the period 641-850 and in 36 years between 851 and 1040) (Popper, 1951, p. 210).

The correlation between calendar year and the date of plenitude (with positive values given to early dates of plenitude) is as strong as 0.407 , and the correlation between time and the maximum level is even stronger (0.597). The changing water level and timing in the inundation of the Nile thus appear to have been helpful to agricultural production. A conclusion is that the high volatility of Cairo grain prices should not be attributed to deteriorating climatic conditions.

\section{CONCLUDING DISCUSSION}

Five main findings emerge from this study:

1. Grain prices (in silver) were higher in Cairo than in Europe during the Middle Ages. Over time, price levels were declining in large parts of Europe but not in Cairo. In this sense, European consumers, unlike those of Egypt, gained from the long-run price trends. The expansion of the Baltic grain trade could be one factor behind the price decline in northwestern Europe.

2. Grain prices also were more volatile in Cairo than in Europe. As a consequence, the population of Cairo must have suffered from violent swings in living standards. High volatility in prices should be seen as a welfare problem, since fluctuations in living conditions led to famine and deterioration of public health. The increased frequency of famine in fifteenthcentury Cairo is well documented. In this sense, many European cities and towns succeeded better.

Over time, volatility was reduced with regard to the cheap grains (barley and beans) at Cairo. This could conceivably have been of importance to large segments of the population, given that demand shifted from wheat to cheaper foodstuffs during the later Middle Ages.

The water level of the Nile was rising in the long term, and failure of plenitude became a rare phenomenon. Climatic change leading to a 
higher water level in the Nile should have contributed to declining price volatility of barley and beans.

3. The Cairo wheat market appears to have been more spatially integrated than the market for barley and beans which had a lower price. This is in accordance with theory and can presumably be explained by the greater role of trade in the wheat market. It may be noted that the transport cost of wheat on the Nile seems to have been low, and is unlikely to have caused the high volatility in prices at Cairo. No price integration can be seen between the European Mediterranean region and Cairo.

4. In north-western Europe, a cluster of urban centers showing similar price movements had emerged in the fourteenth century, at the latest. The degree of price integration reached then did not abate in the century following the Black Death. On the contrary, the economic network appears to have been extended eastwards (though parts of western England were possibly peripheralized). The Mediterranean area was not integrated into this network.

5. Climatic fluctuations (in temperature as well as in the water level of the Nile) did affect Cairo grain prices. High temperatures and low water levels led to rising grain prices. Between 23 percent (wheat) and 31 percent (barley) of the variance in prices could be eliminated by reference to climatic and Nile inundation variance. These are not insubstantial figures.

In Europe, on the other hand, temperature variation in the short term did not have an appreciable impact on prices. It seems that western European price integration cannot be explained by the existence of a common climatic factor.

The more prominent role of climatic factors in Egypt compared to Europe should not be surprising. It lends support to the general view that early European economic development was facilitated by abundant natural resources and a robust environment that was not easily ruined by human activity (Diamond, 1999). In this sense, Europe held a favored position as compared to Egypt and other parts of the Near East.

Ashtor based his view that the Near East started to lag behind Europe during the Middle Ages primarily on his assessment of technological and industrial development. Those aspects have not been studied here. It appears, however, that the study of prices carried out here could be well in line with a more general hypothesis that Europe advanced in two respects during the Middle Ages. First, Europe gained in regional economic integration; second, European consumers enjoyed declining wheat prices. Price 
integration in north-western Europe may have been a factor contributing to the economic advancement of this region in late medieval and early modern times. European wheat price integration could be interpreted as an indication of the emergence of a working market economy well before 1400. Cairo does not show any counterpart to this development.

However, the overall picture is not entirely gloomy for Egypt. With time, prices of cheap grains at Cairo become more stable. As welfare for broad layers of the population of Cairo was at a low and probably declining level, things would have been even worse without this reduction in volatility. This is a point where Europe was less successful: price stability did not generally improve, despite market integration and improvements in transport. Further research is needed to clarify this issue.

\section{NOTES}

1. Ashtor's (1976, pp. 288-331, 1983, pp. 434-440) gloomy view that the economy of fifteenth-century Egypt was in a state of crisis is shared by Darrāg (1961, pp. 57-107), and by Lopez, Miskimin, and Udovitch (1970). The latter authors, however, place greater weight at the devastating long-term effects of the plague than on the policies of the Mamluk rulers. See also Chaudhuri (1990, p. 104), who sees the decline of Egypt and Syria after 1400 as part of a phase of long-term contraction in a wider region.

2. It may be noted, though, that there are no signs of price integration between any of the wheat price series of Cairo, Syria, and Mecca.

3. The gold dinar contained $4.25 \mathrm{~g}$ of gold up to 1425 and thereafter $3.41 \mathrm{~g}$, further reduced to $3.37 \mathrm{~g}$ from 1468; Bacharach (1973, pp. 82-83, 91).

4. Hampel's M-estimator was also computed, but since it gave very similar results to Huber's M-estimator it is not reported in Tables 1-3.

5. Epstein (2001, pp. 159-160) reports a substantial decline in the volatility in European wheat prices during the medieval era. I have been unable to reproduce his results. For instance, Epstein finds a long-term reduction in volatility at Douai, whereas my calculations do not indicate any downward trend.

6. Shoshan (1980, p. 464, Note 9). Another indication of low transport costs is given by al-Maqrizi, who states that the price of one $i r d a b b$ of wheat at one recent occasion reached 500 dirhams of account, out of which only seven dirhams (1.4 per cent) were made up by transport costs. This price presumably refers to Cairo around 1405 . al-Maqrizi does not specify the distance of transportation. Allouche (1994, p. 78).

7. Shoshan (1993, p. 61).

8. Sabra (2000, p. 168). The 10 major food shortages occurred in $1264,1295-1296$, 1336, 1373-1375, 1394-1396, 1402-1404, 1415-1416, 1449-1452, 1469-1470, and 1486-1487; Sabra (2000, pp. 138-164).

9. Falling grain prices should have been beneficial not only to a large part of the urban population, but also to the probably substantial part of the rural population which did not produce a grain surplus. Epstein (2001, pp. 5, 47-48). 
10. Owing to the large number of missing values, it is not meaningful to study market integration at Cairo by calculating correlations between the first differences of grain prices.

11. Alternative series are available. Some of these, such as Crowley (2000), however, use the reconstruction by Mann, Bradley, and Hughes (1998), which has been shown to contain several errors (Mann, Bradley, and Hughes, 2004).

12. There is, however, a significant correlation (at the five per cent level) between Cairo and London wheat prices: $r_{x y}=0.202$ at lag zero when both series are measured as residuals from linear time trends. No direct grain trade took place between these cities. Yet we know that very high prices could trigger a grain trade across larger distances than usual, sometimes even linking the Mediterranean area directly to north-western Europe. For instance, grain was taken directly from the Mediterranean to north-western Europe during the famine of 1317; Spufford (2002, pp. 288, 291). Such high-price years also should have stimulated indirect trade, perhaps through France, creating a network of trading partners. Thus, markets can be integrated without trading directly with each other, as underscored by Ejrnæs and Persson (2000) and Ejrnæs, Persson, and Rich (2004). A comparison between the Cairo and London wheat price series reveals that the observed positive correlation partly was produced by simultaneous high prices in the years 1294-1295, 1308-1309, 1346-1347, 1364, 1374-1375, 1400, and 1409 (Cairo prices are not available for the European famine years of 1316-1317). Still, the observed correlation between Cairo and London is rather weak and could be a chance phenomenon.

13. See, e.g., the information given by Murray (2005, pp. 40-41) on the various trade routes supplying Brugge with grain in the thirteenth and fourteenth centuries.

14. Spufford discerns two semi-integrated grain markets in medieval Europe. One centred on Paris, London, and the Low Countries. The other was in the south, stretching from Andalusia to the grain producing areas around the Black Sea and feeding the north Italian cities; Spufford (2002, p. 288). This characterization would appear to overstate the degree of integration of the southern market. As seen above, prices in Spain and northern Italy did not correlate well. The relatively integrated north Italian market comprised not more than a small part of the vast southern region as delineated by Spufford.

15. Masschaele (1993). Harrison (1992) argues that the construction of a large number of high-quality bridges in medieval England contributed towards creating reasonably good land transport conditions, and gives an indication of the increasing sophistication of the medieval economy. See also Spufford (2002, p. 180) on bridge building as the most important part of road improvement in Europe from the late twelfth to the early fourteenth century.

16. Masschaele (1993, p. 273). My recalculation assumes a price of 6 shillings per quarter of wheat, a normal price in the period 1320-1340; Farmer (1988, p. 795).

17. Hybel (2002, pp. 234-241). See also Hammel-Kiesow (2002, pp. 55, 78-90) arguing that the direct route from Western Europe round northern Jutland to the Baltic Sea was well established already by the mid-thirteenth century.

18. In an alternative specification of the model (not reported in Table 9), Tuscany wheat prices were included as an explanatory variable of Cairo wheat prices, over and above the Nile minimum and maximum water levels and temperature. This inclusion did not, however, improve the model fit. This test thus does not provide 
any support for the hypothesis that trade between Egypt and the northern Mediterranean influenced Cairo prices. Tuscany and Cairo wheat prices do not correlate significantly at any lag. The same is true about Cairo and Sicily (Saint-Séverin) wheat prices, the later series comprising 43 years during the period 1456-1500 as reported by Ashtor (1969, p. 472).

\section{ACKNOWLEDGMENTS}

An earlier version of this paper was presented at the conference Towards a Global History of Wages and Prices, Utrecht, 19-21 August 2004. Thanks to Greg Clark, Phil Hoffman, Paolo Malanima, Sevket Pamuk, Jan Luiten Van Zanden, and other participants for useful comments. Thanks also to Karl Gunnar Persson, Arne Jarrick, Janken Myrdal, Per Simonsson, and an anonymous referee for helpful suggestions.

\section{REFERENCES}

\section{Internet Sources}

Allen, Robert C. \& Unger, Richard W. Allen-Unger database: European commodity prices 1260-1914. www.history.ubc.ca/unger/htm_files/new_grain.htm

Malanima, P. International Institute of Social History: Prices and Wages. Tuscany: www. iisg.nl/hpw/malanima.xls

Verhulst, A. E. Prices of the Sint-Donatiaanskapittel in Brugge, 1348-1800, Brugge. http:// www.iisg.nl/hpw/donat.xls

\section{Published References}

Allouche, A. (1994). Mamluk economics: A study and translation of al-Maqrizi's Ighathah. Salt Lake City: University of Utah Press.

Ashtor, E. (1969). Histoire des prix et des salaries dans l'Orient medieval. Paris: S.E.V.P.E.N.

Ashtor, E. (1976). A social and economic history of the near east in the middle ages. London: Collins.

Ashtor, E. (1977). Quelques problèmes que soulève l'histoire des prix dans l'Orient medieval. In: M. Rosen-Ayalon (Ed.), Studies in memory of gaston wiet (pp. 203-234). Jerusalem: Institute of Asian and African Studies, The Hebrew University of Israel.

Ashtor, E. (1983). Levant trade in the later middle ages. Princeton: Princeton University Press.

Bacharach, J. L. (1973). The Dinar versus the Ducat. International Journal of Middle East Studies, 4, 77-96. 
Bacharach, J. L. (1983). Monetary movements in Medieval Egypt. In: J. F. Richards (Ed.), Precious metals in the Later Medieval and early modern worlds (pp. 159-181). Durham, NC: Carolina Academic Press.

Berger, W. H. (2002). Climate history and the great geophysical experiment. In: G. Wefer, W. H. Berger, K.-E. Behre \& E. Jansen (Eds), Climate development and the history of the Atlantic Realm (pp. 2-16). Berlin: Springer.

Braudel, F., \& Spooner, F. (1967). Prices in Europe from 1450 to 1750. In: Cambridge economic history of Europe, vol. IV: The economy of expanding Europe in the sixteenth and seventeenth centuries (pp. 374-486). Cambridge: Cambridge University Press.

Campbell, B. M. S. (1997). Matching supply to demand: Crop production and disposal by English demesnes in the century of the Black Death. Journal of Economic History, 57, $827-858$.

Chaudhuri, K. N. (1990). Asia before Europe: Economy and civilisation of the Indian Ocean from the Rise of Islam to 1750. Cambridge: Cambridge University Press.

Clark, G. (1999). Markets and economic growth: The grain market of medieval England. Davis: Department of Economics, University of California.

Crowley, T. J. (2000). Causes of climate change over the past 1000 years. Science, 289(14), $270-277$.

Darrāg, A. (1961). L’Égypte sous le règne de Barsbay 825-841/1422-1438. Institut Français d'Études Arabes de Damas: Damascus.

Diamond, J. (1999). Guns, germs and steel: The fates of human societies. New York: W. W. Norton.

Ejrnæs, M., \& Persson, G. (2000). Market integration and transport costs in France 1825-1903: A threshold error correction approach to the law of one price. Explorations in Economic History, 37, 149-173.

Ejrnæs, M., Persson, G., \& Rich, S. (2004). Feeding the British: Convergence and market efficiency in 19th century grain trade. Discussion Papers 04-28, Institute of Economics, University of Copenhagen.

Epstein, S. R. (2000). Market structures. In: W. J. Connell \& A. Zorzi (Eds), Florentine Tuscany: Structures and practices of power. Cambridge: Cambridge University Press.

Epstein, S. R. (2001). Freedom and growth: The rise of states and markets in Europe, 1300-1750. London and New York: Routledge.

Farmer, D. L. (1988). Prices and wages. In: J. Thirsk (Ed.), The agrarian history of England and Wales II. 1042-1350 (pp. 716-817). Cambridge: Cambridge University Press.

Galloway, J. A. (2000). One market or many? London and the grain trade of England. In: J. A. Galloway (Ed.), Trade, urban hinterlands and market integration c. 1300-1600 (pp. 23-42). London: Centre for Metropolitan History, Working Paper Series No. 3.

Hammel-Kiesow, R. (2002). Lübeck and the Baltic trade in bulk goods for the North Sea region 1150-1400. In: L. Berggren, N. Hybel \& A. Landen (Eds), Cogs, cargoes, and commerce: Maritime bulk trade in northern Europe 1150-1400 (pp. 53-91). Toronto: Pontifical Institute of Medieval Studies.

Hanauer, A. C. (1878). Études économiques sur l'Alsace ancienne et moderne (Vol. II). Paris: A. Durand et Pédone-Lauriel.

Harrison, D. F. (1992). Bridges and economic development, 1300-1800. Economic History Review, 45(New Series), 240-261.

Herring, R. S. (1979). Hydrology and chronology: The Rodah nilometer as an aid in dating interlacustrine history. In: J. B. Webster (Ed.), Chronology, migration and drought in interlacustrine Africa (pp. 39-86). London: Longman. 
Hinz, W. (1955). Lebensmittelpreise in mittelalterlichen Vorderen Orient. Die Welt des Orients, 2, 52-70.

Humphries, R. S. (1998). Egypt and the world system in the later middle ages. In: C. F. Petry (Ed.), The Cambridge history of Egypt (Vol. I, pp. 445-461), Islamic Egypt, 640-1517. Cambridge: Cambridge University Press.

Hybel, N. (2002). The foreign grain trade in England, 1250-1350. In: L. Berggren, N. Hybel \& A. Landen (Eds), Cogs, cargoes, and commerce: Maritime bulk trade in northern Europe 1150-1400 (pp. 212-241). Toronto: Pontifical Institute of Medieval Studies.

Jones, P. D., Briffa, K. R., Barnett, T. P., \& Tett, S. B. (1998). High-resolution palaeoclimatic records for the last millennium: Interpretation, integration and comparison with general circulation model control-run temperatures. The Holocene 8, 455-471. Data source: Jones, P. D., Briffa, K. R., Barnett, T. P., \& Tett, S. F. B. (1998). Millennial temperature reconstructions. IGBP PAGES/World Data Center-A for Paleoclimatology, data contribution series \#1998-039, NOAA/NGDC Paleoclimatology Program, Boulder CO, USA. Downloadable data: ftp://ftp.ngdc.noaa.gov/paleo/contributions_by_author/jones1998.

Lopez, R., Miskimin, H., \& Udovitch, A. (1970). England to Egypt, 1350-1500: Long-term trends and long-distance trade. In: M. A. Cook (Ed.), Title Studies in the economic history of the middle East from the Rise of Islam to the present day (pp. 93-128). London: Oxford University Press.

Mann, M. E., Bradley, R. S., \& Hughes, M. K. (1998). Global-scale temperature patterns and climate forcing over the past six centuries. Nature, 392(23), 779-787.

Mann, M. E., Bradley, R. S., \& Hughes, M. K. (2004). Corrigendum. Nature, 430(1), 105.

Masschaele, J. (1993). Transport costs in medieval England. Economic History Review, 46(New Series), 266-279.

Mortel, R. T. (1989). Prices in Mecca during the Mamluk period. Journal of the Economic and Social History of the Orient, 32, 279-334.

Murray, J. M. (2005). Bruges, cradle of capitalism, 1280-1390. Cambridge: Cambridge University Press.

Persson, K. G. (1999). Grain markets in Europe, 1500-1900. Cambridge: Cambridge University Press.

Popper, W. (1951). The Cairo nilometer: Studies in Ibn Taghrî Birdîs chronicles of Egypt (Vol. 1). Berkeley and Los Angeles: University of California Press.

Popper, W. (1957). Egypt and Syria under the Circassian Sultans 1382-1468 A.D.: Systematic notes to Ibn Taghrî Birdîs chronicles of Egypt. P. [2]. Berkeley and Los Angeles: University of California Press.

Rabie, H. (1981). Some technical aspects of agriculture in Medieval Egypt. In: A. L. Udovitch (Ed.), The Islamic Middle East, 700-1900: Studies in economic and social history (pp. 59-90). Princeton, NJ: Darwin Press.

Sabra, A. (2000). Poverty and charity in Medieval Islam: Mamluk Egypt, 1250-1517. Cambridge: Cambridge University Press.

Shoshan, B. (1980). Grain riots and the 'moral economy': Cairo, 1350-1517. Journal of Interdisciplinary History, 10, 459-478.

Shoshan, B. (1983). Money supply and grain prices in fifteenth-century Egypt. Economic History Review, 36(2nd ser.), 47-67.

Shoshan, B. (1986). Exchange-rate policies in fifteenth-century Egypt. Journal of the Economic and Social History of the Orient, 29, 28-51.

Shoshan, B. (1993). Popular culture in Medieval Cairo. Cambridge: Cambridge University Press. 
Spufford, P. (1986). Handbook of medieval exchange. London: Office of the Royal Historical Society.

Spufford, P. (2002). Power and profit: The merchant in Medieval Europe. London: Thames \& Hudson.

Toussoun, O. (1922). Aboul Mahasin (année 874 Hégire $=1470$ ère chrétienne). Mémoires présentés à l'Institut d'Égypte, 4, 135-145.

Verlinden, C. (1959). Dokumenten voor de geschiedenis van prijzen en lonen in Vlaanderen en Brabant. [D. 1], XVe-XVIIe eeuw. Brugge: De Tempel. 